\title{
Effect of infestation by Micrapate scabrata (Erichson, 1847) (Coleoptera: Bostrichidae) on wood degradation and its impacts on some soil chemistry properties
}

\section{Efecto de la infestación de Micrapate scabrata (Erichson, 1847) (Coleoptera: Bostrichidae) en la degradación de madera y sus consecuencias en algunas propiedades químicas del suelo}

\author{
Tomislav Curkovic ${ }^{1 *}$, Catalina Ferrera ${ }^{1}$, Cecilia Baginsky² \& Oscar Seguel ${ }^{3}$ \\ 1Departamento de Sanidad Vegetal, Facultad de Ciencias Agronómicas, Universidad de Chile, PO Box 1004, Santiago, Chile. \\ 2Departamento de Producción Agrícola, Facultad de Ciencias Agronómicas, Universidad de Chile, PO Box 1004, Santiago, Chile. \\ ${ }^{3}$ Departamento de Ingeniería y Suelos, Facultad de Ciencias Agronómicas, Universidad de Chile, PO Box 1004, Santiago, Chile. \\ *E-mail: tcurkovi@uchile.cl
}

\begin{abstract}
Micrapate scabrata (Erichson) (Coleoptera: Bostrichidae) is a xylophagous beetle native to Chile. Adults and larvae feed on several native host plants, but also on pruned wood of exotic plants. In this study we assessed the impact of artificial M. scabrata infestation on Vitis vinifera L. wood degradation and the subsequent changes in soil properties. First, we periodically sampled, during a four-month period, pruned wood from an infested table grape vineyard, finding in average 1 adult $/ 10 \mathrm{~cm}$ linear wood. Adults were then placed in large Petri dishes containing uninfested wood samples, and maintained in a climatic chamber for six months. At the end of this period, an average of $65.6 \%$ of infested wood had been turned mainly into sawdust. Additionally, the impact of leaving M. scabrata infested pruned wood on potted soil for six months, under laboratory conditions, was also evaluated. Afterwards, the surface soil content of macro elements (N-P-K) and organic matter significantly increased, whereas the soil $\mathrm{pH}$ decreased. These results document the significant impact of $M$. scabrata infestation on pruning wood degradation and the benefits to the soil if left on the ground in the ecosystem.
\end{abstract}

KEYWORDS: Ecosystems, soil improvement, wood recycling, xylophagous beetles

\begin{abstract}
RESUMEN
Micrapate scabrata (Erichson) (Coleoptera: Bostrichidae) es una especie xilófaga y nativa de Chile. Las larvas y los adultos se alimentan de madera de varias especies nativas, y también de madera de poda de plantas exóticas. En este estudio evaluamos el impacto de una infestación artificial de M. scabrata en la degradación de madera de Vitis vinifera L. y los cambios subsecuentes en las propiedades del suelo. Para ello, primero muestreamos madera de poda, durante cuatro meses, en un parronal de uva de mesa infestado, y encontramos en promedio 1 adulto/10 cm lineales de madera. Luego se infestó madera de poda sana, dispuesta en placas de Petri, con adultos, las que se mantuvieron en una cámara climática por seis meses. En ese plazo, un $65.6 \%$ de la madera infestada fue convertida principalmente en aserrín. Adicionalmente, se evaluó el efecto de dejar madera de poda infestada por M. scabrata en macetas con suelo, durante seis meses, en condiciones de laboratorio. Luego de ese período, se encontró que el contenido de macro-elementos (N-P-K) y materia orgánica en el suelo aumentó significativamente, mientras que el pH disminuyó. Estos resultados muestran el impacto significativo de la infestación de madera por M. scabrata en su degradación y los beneficios para la condición del suelo si es dejado en superficie en el ecosistema.
\end{abstract}

Palabras clave: Ecosistemas, escarabajos xilófagos, mejoramiento del suelo, reciclaje de madera.

\section{INTRODUCTION}

Micrapate scabrata (Erichson) (Coleoptera: Bostrichidae) is a species found in Chile between Arica and Temuco (18 $38^{\circ} \mathrm{S}$ ), and also in some regions of Peru and Bolivia (Artigas
1994). It is a xylophagous (saproxylophagous, Muñoz-López et al. 2016) species that is commonly found in wine grape vineyards (Vitis vinifera L.), and more occasionally in table grapes and kiwis (Actinidia deliciosa (Chev.) (Prado 1991, Gonzalez \& Curkovic 1994, Klein \& Waterhouse 2000). 
The adult usually feeds on dry and dead wood (Figure 1A) of several plant species (Barriga et al. 1993), but it has also been occasionally found boring live tissues from stressed vines (e.g. following water stress) (Ripa \& Luppichini 2004). Our understanding of the life cycle of M. scabrata is fragmentary. Eggs are apparently laid inside the wood. Larvae (Figure 1B) actively feed inside pruned branches and trunks, consuming mainly xylem and phloem tissues, and producing large amounts of frass in the form of sawdust (Figure 1C). Pupae occur in brief bursts. Apparently there are two or three generations per year (Artigas 1994). The attack on live plants causes branch fractures and reduces plant sprouting and canopy development (unpublished data). The consumption of large amounts of dry wood by adults and larvae, and the subsequent sawdust produced, are usually seen as biodeterioration of a material which otherwise decomposes very slowly (Harmon et al. 1986). However, bostrichid species (among other decomposition agents) also act as wood transformers, contributing to its biodegradation (Harmon et al. 1986). The objectives of this study were a) to evaluate the abundance of M. scabrata adults on infested table grapes prunings, $b$ ) to measure wood degradation after M. scabrata infestation, and c) to measure the impact of naturally deposited sawdust from infested wood on several soil chemical parameters.
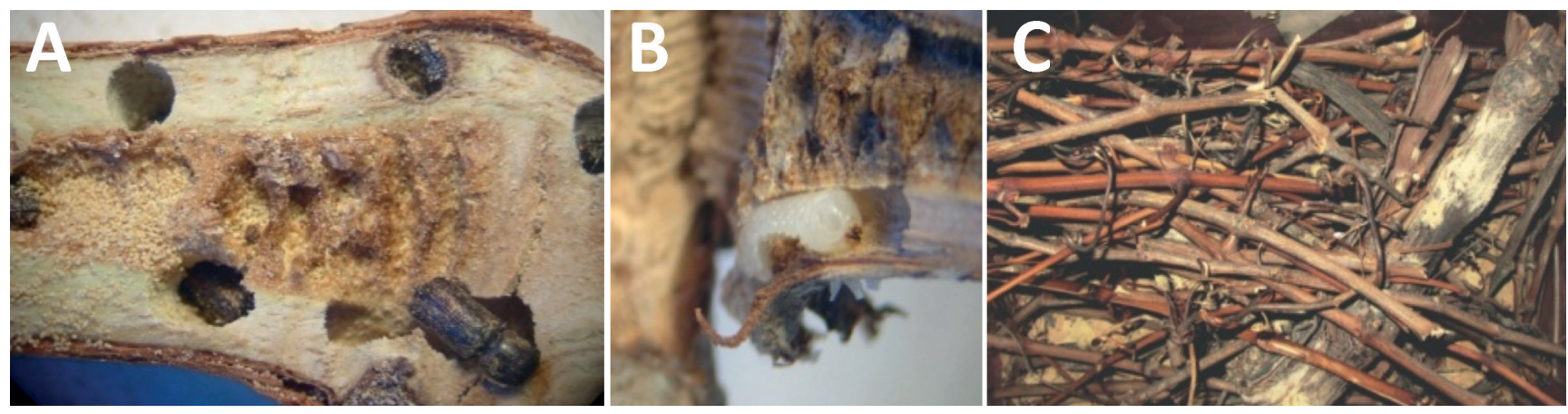

FiguRE 1. Micrapate scabrata: adults feeding on V. vinifera pruned wood (A); larvae inside a gallery located under bark, boring wood (B); pruned wood and sawdust produced by a severe infestation, in a M. scabrata colony under laboratory conditions (C). / Micrapate scabrata: adultos alimentándose de madera de poda de $V$. vinifera (A); larva en una galería ubicada bajo la corteza, taladrando la madera (B); madera de poda y aserrín producido por una infestación severa, en una colonia de M. scabrata mantenida en condiciones de laboratorio (C).

\section{MATERIALS AND METHODS}

WoOd SOURCE AND M. SCABRATA INFESTATION. Residual table grapevine wood pieces (from the pruning season) of about 1 $\mathrm{cm}$ in diameter and $\sim 1 \mathrm{~m}$ in length were collected ca. once a week (September through January) from a table grape vineyard (cv. Red Globe) located near "Alto del Carmen" $\left(29^{\circ} 45^{\prime} 34^{\prime \prime} \mathrm{S}, 70^{\circ} 5^{\prime} 15^{\prime \prime} \mathrm{W}\right)$, region of Atacama, Chile. Typically, pruning is conducted at the end of May and the pruned wood is left on the vineyard ground, sometimes forming an extensive cover. Micrapate scabrata presence was confirmed in the field. The number of $M$. scabrata individuals (larvae, pupae, and adults) on the wood samples was recorded in the laboratory. The adults were used to start a colony in Flanders batteries on wine grape pruned wood in the laboratory. Recently emerged (less than a week old) beetles were used for experiments 1 and 2 (1:1 sex ratio, based on Artigas 1994).

EXPERIMENT 1. WOOd INFESTATION WITH M. SCABRATA IN Petri Dishes. Ten pieces of table grapevine wood $(\sim 61-71$ $\mathrm{cm}$ long) without signs of $M$. scabrata infestation were selected and one end of each piece was cut, weighed (fresh), and dried in a muffle at $70^{\circ} \mathrm{C}$ until constant weight. Then, the water content $/ \mathrm{cm}$ of wood end pieces was calculated ([fresh - dry] weight $(\mathrm{g}) /$ length $(\mathrm{cm})$ ). The remainder of each wood piece ( $60 \mathrm{~cm}$ long each) was also weighed and the initial dry weight estimated (individually corrected for water loss). Each remaining $60 \mathrm{~cm}$ wood sample (the section not dried in the muffle) was cut in six smaller pieces $(\sim 10 \mathrm{~cm}$ ea.) and placed inside a large Petri dish $(\mathrm{n}=10)$. Five Petri dishes (replicates) were randomly chosen and six M. scabrata adults/dish were added to group 1, whereas the other five Petri dishes were not infested with insects group 2. All Petri dishes were then sealed and placed inside the climatic chamber $\left(25 \pm 2{ }^{\circ} \mathrm{C}, 45 \pm 5 \% \mathrm{RH}, 14 \mathrm{~h}\right.$ of light $)$ for 180 days (May to October), at the Insect Behavior and Chemical Ecology Laboratory, Department of Crop Protection, College of Agricultural Sciences, University of Chile. Afterwards, the wood pieces from each Petri dish were cleaned with a brush (to remove the sawdust) and taken into a muffle until stable weight (final dry weight). The transformed wood weight (initial-final) after the sixmonth period was calculated.

EXPERIMENT 2. WOOD INFESTATION WITH M. SCABRATA IN 
POTS WITH SOIL SAMPLES. The soil used in this experiment was collected from the table grape vineyard as described above. This soil is an Aridisol (CIREN 2007) developed from stony colluvial deposits in the Huasco Valley, with a loamy sand texture. A preliminary soil analysis showed values of total $\mathrm{N}$ and organic matter $(\mathrm{OM})$ of $0.07 \%$ and $2.17 \%$ respectively, $18.5 \mathrm{mg} \mathrm{kg}^{-1}$ of P-Olsen, $0.21 \mathrm{cmol}$ $\mathrm{kg}^{-1}$ of $\mathrm{K}$ and $\mathrm{pH}=7.98$. Soil samples (taken at 0 to $15 \mathrm{~cm}$ in depth) were collected and placed in $4.3 \mathrm{~L}$ plastic pots $(n=10)$. In order to maintain the wood/topsoil proportion close to that of the field conditions, $100 \mathrm{~cm}$ of uninfested pruned wood pieces $(1 \mathrm{~cm}$ in diameter and ca. $50 \mathrm{~g})$ were left on the surface of each pot. Two groups of five pots were randomly chosen and ten $M$. scabrata adults/pot were added to one group (infested treatment), whereas the other one was not infested. All pots were then covered with an anti-aphid mesh to prevent further infestation (or escape) and kept under room conditions $\left(20 \pm 5^{\circ} \mathrm{C}, 40 \pm 5 \% \mathrm{RH}, 10-14 \mathrm{~h}\right.$ of light) for 180 days (June to November). Subsequently, the soil chemical properties mentioned above were measured in a sample collected from the first $5 \mathrm{~cm}$ of soil.

Evaluation of soll parameters. Soil properties were evaluated according to the methodologies proposed by Sadzawka et al. (2004) adapted to Chilean soils: total N was measured by modified Kjeldahl method, available $\mathrm{P}$ by P-Olsen method, exchangeable $\mathrm{K}$ by $\mathrm{NH}_{4}$-Ac $(1 \mathrm{~mol} / \mathrm{L})$ at $\mathrm{pH} 7.0$ and determination by atomic emission spectrometry, $\mathrm{OM}$ by acid combustion (Walkley-Black), and $\mathrm{pH}$ by potentiometry in soil to water ratio of 1:2.5.

EXPERIMENTAL DESIGN AND DATA ANALYSIS. Data for $M$. scabrata infestation is presented as the mean value. A completely randomized experimental design was used, with five replicates for each experiment (1 and 2). Data were analyzed by using one-way ANOVA ( $\mathrm{p} \leq 0.05)$. In the first experiment, we compared the weights of the wood samples between (infested vs. uninfested) and within (initial vs. final dry weight) treatments (Ott 1992). For the second experiment, after the six-month period, the macronutrients, OM content, and soil $\mathrm{pH}$ were contrasted between treatments. The ANOVA was conducted based on the assumption of independence among the variables measured on the same soil samples (Nielsen \& Wendroth 2003). ANOVA assumptions were confirmed for most data. For total OM, the values were transformed to square root to accomplish normality. The nitrogen content was not normal, thus the Kruskal-Wallis nonparametric test was used to contrast data (Steel \& Torrie 1985).

\section{RESULTS}

EXPERIMENT 1: WoOd InFESTATION AND Degradation. About $20 \mathrm{~m}$ of infested pruned wood were collected and dissected between September and January. Micrapate scabrata was the only xylophagous species reared from the samples, resulting in an average of 1.35 exit holes, 0.40 larvae, 0.18 pupal chambers, 0.01 pupae, and ca. 1 adult, per 10 linear $\mathrm{cm}$ of wood. Therefore, this density of adults was used for experimental infestation of Petri dishes and potted soil. No parasitic or predatory species were found.

The water content ( $\mathrm{g} /$ linear $\mathrm{cm}$ of wood) found in the samples, before M. scabrata infestation, ranged between 0.028 and $0.043 \mathrm{~g} \mathrm{~cm}^{-1}$ (group 1) and 0.025 and $0.043 \mathrm{~g} \mathrm{~cm}^{-1}$ (group 2). After subtracting the water content, the corrected dry weight of wood samples ranged between 24.08 and $28.14 \mathrm{~g} \mathrm{~cm}^{-1}$ of wood (group 1) and between 24.63 and 28.28 $\mathrm{g} \mathrm{cm}^{-1}$ (group 2), without significant differences between groups ( $\mathrm{p}=0.57$ ) (Table 1). Six months after M. scabrata infestation in group 1 dishes, the dry weight of wood ranged between 6.70 and $11.39 \mathrm{~g} \mathrm{~cm}^{-1}$, whereas in the uninfested wood (group 2) it ranged between 23.99 and $27.40 \mathrm{~g} \mathrm{~cm}^{-1}$, the treatments being significantly different $(p<0.0001)$. There were no significant differences within group 2 (uninfested wood) before and after six months ( $\mathrm{p}=0.33$ ), whereas highly significant differences were found when comparing wood weight in group 1 of infested dishes before and after placing the adults in the dishes $(\mathrm{p}<0.0001)$. An average of at least $65 \%$ of infested wood, after correction for water loss, was converted mainly into sawdust by $M$. scabrata after six months of exposure (neither M. scabrata final biomass, nor density was measured). In contrast, only $4.7 \%$ of the weight was lost during the same period in uninfested wood.

TABLE 1. Weight and water content ( $\mathrm{g}$ ) of pruned wood of table grapevines, with and without Micrapate scabrata infestation, after six months inside a Petri dish in a climatic chamber $\left(25 \pm 2{ }^{\circ} \mathrm{C}, 45 \pm 5 \% \mathrm{RH}, 14 \mathrm{~h}\right.$ of light). / Peso y contenido de agua de madera de poda de vides de mesa, con y sin infestación de Micrapate scabrata, después de seis meses almacenadas en placas de Petri en una cámara climática $\left(25 \pm 2{ }^{\circ} \mathrm{C}, 45 \pm 5 \% \mathrm{HR}, 14 \mathrm{~h}\right.$ de luz $)$.

\begin{tabular}{lccccc}
\hline Treatment & Fresh & Water Content $^{1}$ & Initial Dry $^{2}$ & Final Dry & $\Delta$ Dry $^{3}$ \\
\hline Infested & $27.72 \mathrm{a}$ & $2.12 \mathrm{a}$ & $25.60 \mathrm{aA}$ & $8.80 \mathrm{bB}$ & $16.81 \mathrm{a}$ \\
Uninfested & $28.50 \mathrm{a}$ & $2.15 \mathrm{a}$ & $26.35 \mathrm{aA}$ & $25.18 \mathrm{aA}$ & $1.18 \mathrm{~b}$ \\
\hline
\end{tabular}

${ }^{1}$ [(fresh - dried wood weight of end piece)/end piece length] $* 60 \mathrm{~cm} ;{ }^{2}$ initial fresh weight - water content; ${ }^{3}$ initial dry weight -final dry weight. Small letters show statistically significant differences between treatments within a column, while capital letters show significant differences between dry wood weights (initial vs. final), one-way ANOVA ( $p \leq 0.05)$. 
Infested wood at the end of the experiment turned into a large amount of sawdust (frass), due to the consumption of most wood (i.e. mostly xylem + phloem) by M. scabrata, while only a thin layer of bark persisted almost unchanged externally, except for the holes bored by the adults. These holes allowed sawdust to exit and end up on the dish bottom. The uninfested wood pieces remained unchanged after sixmonth period.

EXPERIMENT 2. EFFECTS ON SOIL PROPERTIES. The impacts of M. scabrata infestation on the macro elements (N-P-K), $\mathrm{OM}$ content, and soil $\mathrm{pH}$ of wood pieces placed in pots with soil samples are shown in Table 2. The main effects should be caused by the sawdust produced by the infestation and released on the soil, since it should correspond at least to $92 \%$ out of the total weight (beetles should be under $8 \%$, estimated based on unpublished data). When looking at the original values for soil characteristics, most parameters showed equal or greater values in the treatment with infested wood, whereas the opposite occurred with uninfested wood. Only $\mathrm{pH}$ values were higher in the uninfested treatment. Although the differences between both treatments were not very large, all measurements, except $\mathrm{pH}$, were statistically greater when wood was infested with $M$. scabrata adults. The higher increases (with regard to the level found in uninfested wood) were obtained in OM content (ca. 63\%) and $\mathrm{P}(40 \%)$, whereas the lowest variations were observed in $\mathrm{N}(17 \%)$ and $\mathrm{K}(11 \%)$. The $\mathrm{pH}$ showed a small but significant reduction of $3 \%$, taking the soil from a moderately alkaline condition to a value $<8.0$ in the $M$. scabrata infestation treatment.

TABLE 2. Macro elements (N-P-K), OM content, and pH levels in soil samples with pruned wood infested (with M. scabrata) or uninfested, and kept for six months in pots under laboratory conditions $\left(20 \pm 5{ }^{\circ} \mathrm{C}, 40 \pm 5 \% \mathrm{RH}, 14 \mathrm{~h}\right.$ of light). / Niveles de macro-elementos (N-P-K), contenido de materia orgánica y $\mathrm{pH}$, en muestras de suelo con madera de poda de vides infestada (con $M$. scabrata) o no infestada, y mantenida por seis meses en macetas bajo condiciones de laboratorio $\left(25 \pm 2{ }^{\circ} \mathrm{C}, 45 \pm 5 \% \mathrm{HR}, 14 \mathrm{~h}\right.$ de luz $)$.

\begin{tabular}{lccccc}
\hline Treatments & $\begin{array}{c}\mathrm{N} \\
(\%)\end{array}$ & $\begin{array}{c}\mathrm{P} \\
\left(\mathrm{mg} \mathrm{kg}^{-1}\right)\end{array}$ & $\begin{array}{c}\mathrm{K} \\
\left(\mathrm{cmol}^{+} \mathrm{kg}^{-1}\right)\end{array}$ & $\begin{array}{c}\mathrm{OM} \\
(\%)\end{array}$ & $\mathrm{pH}$ \\
\hline Infested & $0.07 \mathrm{a}$ & $20.4 \mathrm{a}$ & $0.21 \mathrm{a}$ & $2.39 \mathrm{a}$ & $7.94 \mathrm{~b}$ \\
Uninfested & $0.06 \mathrm{~b}$ & $14.6 \mathrm{~b}$ & $0.19 \mathrm{~b}$ & $1.47 \mathrm{~b}$ & $8.16 \mathrm{a}$ \\
\hline
\end{tabular}

Small letters show statistically significant differences between treatments within a column. Data were submitted to one-way ANOVA ( $\mathrm{p}$ $\leq$ 0.05). Data were square-root transformed for total OM. The Kruskal-Wallis nonparametric test was used to contrast nitrogen content.

\section{DISCUSSION}

The presence of large larvae and pupae infesting sampled wood suggests the infestation begun several months earlier, probably at the beginning of the autumn, during the last generation of the season based on Artigas (1994) and Ripa \& Luppichini (2004). The wood consumption by $M$. scabrata has not been studied, but our results showed wood pieces about $1 \mathrm{~cm}$ diameter (fine debris following Brin et al. 2011) were intensively damaged. Field observations also suggest that $M$. scabrata prefers wood pieces of smaller diameters $(1-3 \mathrm{~cm})$ to bore and reproduce. Wood size determines preference in many xylophagous beetles (Grove 2002). For instance, Stephanopachys quadricollis (Marseul), a relatively small-sized bostrichid $(\sim 6 \mathrm{~mm}$ length), is reported to attack mostly large logs (Brin et al. 2011), whereas Dexicrates robustus (Blanchard), a larger bostrichid (up to $18 \mathrm{~mm}$ ), mainly bores trunks and branches in young orchards (González \& Curkovic 1994). Micrapate scabrata seems to present an unusual strategy, boring small diameter wood pieces.

Based on our data, the transformation of grapevine pruned to degraded wood (mostly turned into sawdust) and its contribution to soil fertility were significant in a period of six-month under experimental conditions. These results support the idea that this type of species significantly aid in nutrient conservation in the ecosystems by modifying both, physically and chemically woody debris (Chen \& Forschler 2016). This is well recognized in xylophagous species such as termites (Isoptera), but considerably less known and studied in the case of Bostrichidae, usually one of the least abundant families in ecological studies (Muñoz-López et al. 2016). Despite the fact that bostrichid species have been reported as important wood pests, they are also considered wood transformers (Harmon et al. 1986). Both larvae and adults feed on dry wood, being able to digest starches and sugars (Liu et al. 2008), having endosymbiotic relationships with microorganisms that can provide cellulolytic enzymes and aid for digestion of other important wood constituents (Beaver et al. 2011) such as cellulose, lignin, and hemicellulose. Bostrichid feeding activities generate large amounts of feces or frass (sawdust) due to a partial digestibility (50\%). Studies on xylophagous frass content have shown important significant lignin transformation and oxidation of elements after passing through the insect's alimentary canal. In fact, bostrichid frass showed 
significantly greater concentrations of phosphorus than the original wood (pinewood). On the other hand, nitrogen and potassium were not different from the wood the insects fed on (Chen \& Forschler 2016). Ulyshen (2016) states that wood degradation is largely driven by microbes. However, invertebrates play an important role as well (10-20\% wood degradation) by performing enzymatic digestion, substrate alteration (e.g. tunneling), biotic interactions, and nitrogen fertilization, having a cumulative effect that speeds up the degradation process.

According to Wang \& Shuchardt (2010), vineyard pruning residues can contain an average of $7.2 \mathrm{~g} \mathrm{~kg}^{-1}$ of N, $1.1 \mathrm{~g} \mathrm{~kg}^{-1}$ of $\mathrm{K}$ and $5 \mathrm{~g} \mathrm{~kg}^{-1}$ of $\mathrm{P}$, with high OM content $(>90 \%)$. Assuming the production of $0.75 \mathrm{~kg}$ (dry weight) of pruned grapevine wood/plant (Lavin 1981, OrtegaFarias et al. 2007) and considering the average proportion of wood transformed into sawdust and M. scabrata (65.6\%, see above), we estimate a potential of about 0.50 $\mathrm{Mg}$ (1,000 plants/ha for table grape vineyard) to $1.23 \mathrm{Mg}$ (2,500 plants/ha for wine grape vineyard) of available OM to be incorporated into the topsoil. The addition of organic debris on the soil surface has beneficial effects on soil properties, such as higher water retention and porosity, and lower compaction (Hartge \& Bachmann 2004, Mulumba $\&$ Lal 2008). However, in materials with high (e.g. 49\%) lignin content and high (e.g. 60 to 89$) \mathrm{C} / \mathrm{N}$ ratio, such as table grapevine prunings (Sanchez et al. 2002, Wang et al. 2005), the residue pieces persists for longer time, thus the temperature of the soil tends to decrease (Wang \& Schuchardt 2010), leading to nutrient depletion (Powlson et al. 2011). In this sense, the activity of M. scabrata on prunings promotes nutrient recycling by a faster initial decomposition, improving ecosystem conditions. Regarding OM, in a study conducted by Tahboub et al. (2008) where pecan wood chips were incorporated into the soil in amounts ranging from ca. $4.5 \mathrm{Mg}$ to ca. $18 \mathrm{Mg}$ of wood ha' (fresh weight), no significantly increasing levels were observed after one year, regardless of the amount of incorporated wood. However, when chipped wood was incorporated the second study year, significantly greater OM levels were obtained. In our case M. scabrata speeded up the process of wood degradation and incorporation into the soil within a relatively short period (six months), increasing the OM content compared with the initial soil condition $(2.17 \%$ OM measured immediately before setting Experiment 2) while in the uninfested treatment the OM decreased. In this sense, high commercial yields (along with greater pruned wood production) in the vineyard under study $(>24$ $\mathrm{Mg} \mathrm{ha}^{-1}$ ), allowed a high addition of pruned wood on the topsoil, causing beneficial effects on the soil if M. scabrata infestation occurs on the wood debris. Exchangeable K was moderate to low in both treatments, requiring a supplement for the grapevine production (Havlin et al. 2005). Finally, the P-Olsen values showed a significant increase, changing from moderate content without $M$. scabrata infestation to high content in the treatment with infested wood. In practical terms, considering an Ap horizon of $20 \mathrm{~cm}$ deep, the treatment with $M$. scabrata provided an extra supply of $26 \mathrm{~kg} \mathrm{P}_{2} \mathrm{O}_{5}$ per hectare, a beneficial effect (ecological service) in $\mathrm{P}$ availability for plants. Soil $\mathrm{pH}$ levels decreased significantly due to the activity of $M$. scabrata on pruned wood. Tahboub et al. (2008) find no statistical differences even after three years of reiterative amendments of pecan wood (not infested by xylophagous insects) into the soil; however, when inorganic $\mathrm{N}$ was added, $\mathrm{pH}$ values dropped significantly. In our study, the reduction of $\mathrm{pH}$ from 8.16 to 7.94 , though small, is still relevant because agricultural crops respond better to soil $\mathrm{pH}$ below 8.0; otherwise, many nutrients are not available and $\mathrm{Na}^{+}$excess can make the absorption of bivalent cations difficult (Havlin et al. 2005).

Mulching of pruning debris on the ground, between the rows of a table grape vineyard, is a common and practical procedure with positive impacts on the soil properties under the semiarid Chilean conditions, particularly in terms of soil fertility, structure, and water retention (Baginsky et al. 2010). Our results showed that the activity of M. scabrata accelerated wood residue decomposition, increasing macro elements availability. This is particularly important in areas such as the Atacama Region, a semiarid zone, where soils are shallow and low in OM content, significantly reducing yields if these conditions are not improved. Besides, although there is a risk of $M$. scabrata attacking weak or stressed plants (Ripa \& Luppichini 2004), no $M$. scabrata infestation was observed on live plants during the sampling period in the vineyard. Therefore, these results stress the usefulness of leaving pruned wood infested with xylophagous insects on the vineyard soil, provided the grapevines are not stressed and, therefore, susceptible to M. scabrata damage. Similar results should be expected if the wood debris were left on non-agricultural soils (e.g. in wild areas) in Chile where M. scabrata, among other wood decomposers, causes wood degradation. Unlike cultivated species, the risk from M. scabrata to the natural vegetation is considered very low since this species has been reported attacking only dead wood in a restricted range of native host plants (Baccharis linearis (Ruiz \& Pav.), Chusquea culeou Desv., and Prosopis chilensis (Mol.) Stuntz., Barriga et al. 1993) and there are no reports of damage on indigenous stressed plants by this insect. However, in other countries the activity of bostrichids in forests produces large amounts for organic compounds that end up in the soil (Harmon et al. 1986, De Souza 2010). Bostrichids are considered among the key species responsible of improving soil fertility by nutrient recycling in woods and energy flow in many ecosystems (Harmon et al. 1986, Nadeau et al. 2015). However, forest management can reduce their densities and affects their role in wood decomposition (Grove 2002).

In conclusion, Micrapate scabrata as described in here, 
had a significant and positive impact on the degradation of wood (table grapevine prunings), turning at least $65 \%$ mainly into sawdust within a six-month period and providing significant ecosystem services in nutrient recycling. This resulted in a significant increase of both the $\mathrm{OM}$ and macro element contents (N-P-K) in the surface soil layer, and in a significant decrease of soil $\mathrm{pH}$. All these changes are considered to be a significant improvement of the soil conditions for growing crops, agroecosystems, or wild ecosystems (as native forests) where M. scabrata should play a significant role in its sustainability.

\section{ACKNOWLEDGMENT}

To InnovaChile from "Corporación de Fomento de la Producción (CORFO)" for funding the grant 05CR11IAT-06 "Suelo vivo. Innovación y cambios tecnológicos en el uso de la materia orgánica en la optimización del manejo de parronales en la tercera región”.

\section{REFERENCES}

Artigas, J. 1994. Entomología Económica. Insectos de interés agrícola, forestal, médico y veterinario (nativos, introducidos y susceptibles de ser introducidos). Ediciones Universidad de Concepción. Concepción, Chile. Vol. 2, $943 \mathrm{pp}$.

Baginsky, C., Seguel, O., Contreras, A. 2010. Impacto de la utilización de cultivos y enmiendas orgánicas sobre la funcionalidad del suelo. Facultad de Ciencias Agronómicas, Universidad de Chile, Serie Ciencias Agronómicas No17. Santiago, Chile. 122 pp.

Barriga, J.E., Curkovic, T., Fichet, T., Henríquez, J.L., Macaya, J. 1993. Nuevos antecedentes de coleópteros xilófagos y plantas hospederas en Chile, con una recopilación de citas previas. Revista Chilena de Entomología 20:65-91.

Beaver, R.A., Sittichaya, W., Liu, L.Y. 2011. A Review of the Powder-Post Beetles of Thailand (Coleoptera: Bostrichidae). Tropical Natural History 11(2):135-158.

Brin, A., Bouget, C., Brustel, H., Jactel, H. 2011. Diameter of downed woody debris does matter for saproxylic beetle assemblages in temperate oak and pine forests. Journal of Insect Conservation 15(5):653-669.

Chen, Y., Forschler, B.T. 2016. Elemental concentrations in the frass of saproxylic insects suggest a role in micronutrient cycling. Ecosphere 7(3):e01300.10.1002/ecs2.1300

Ciren. 2007. Estudio Agrológico Valle de Copiapó y Valle del Huasco III Región. Centro de Información de Recursos Naturales Publicación 135. Santiago, Chile. 145 pp.

De SouzA, C. 2010. Ocorréncia de coleópteros degradadores de madeira sob influéncia de diferentes espacamentos em plantios florestais. Thesis Engenharia Florestal. Universidade Federal Rural do Rio do Janeiro, Seropédica, Brazil.

Gonzalez, R., Curkovic, T. 1994. Manejo de plagas y degradación de residuos de pesticidas en kiwi. Revista Frutícola 15(1):5-20

Grove, S.J. 2002. Saproxylic insect ecology and the sustainable management of forests. Annual Review of Ecology and Systematics 33:1-23.

Harmon, M., Franklin, J., Swanson, F., Sollins, P., Gregory, S., Lattin, J., Anderson, N., Cline, S., Aumen, N., Sedell, J., Lienksemper, G., Cromack, K., Cummins, K. 1986. Ecology of coarse woody debris in temperate ecosystems. Advances in Ecological Research 15:133-302.

Hartge, K., Bachmann, J. 2004. Ermittlung des Spannungszustandes von Böden aus Werten des Eindringwiderstandes von Sonden. Journal of Plant Nutrition and Soil Science 167(3):303-308.

Havlin, J., Tisdale, S., Nelson, W., Beaton, J. 2005. Soil fertility and fertilizers: An introduction to nutrient management. Pearson Prentice Hall, Upper Saddle River, USA. 515 pp.

Klein, C., Waterhouse, D. 2000. The Distribution and Importance of Arthropods Associated with Agriculture and Forestry in Chile (Distribución e importancia de los artrópodos asociados a la agricultura y silvicultura en Chile). ACIAR Monograph 68, Canberra, Australia. 234 pp.

Lavín, A. 1981. Racionalización de la poda de producción de viñedos cv. País conducidos en cabeza. Agricultura Técnica 41(3):127-132.

Liu, L.Y., Schonitzer, K., Yang, J.T. 2008. A review of the literature on the life history of Bostrichidae (Coleoptera). Mitteilungen der Munchner Entomologischen Gesellschaft 98:91-97.

Mulumba, L., Lal, R. 2008. Mulching effect on selected soil physical properties. Soil and Tillage Research 98(1):106111.

Muñoz-Lopez, N.Z., Andrés-Hernández, A.R., CARrillo-Ruiz, H., Rivas-ArancibiA, S.P. 2016. Coleoptera associated with decaying wood in a tropical deciduous forest. Neotropical Entomology 45(4):341-350.

Nadeau, P., Thibault, M., Horgan, F.G., Michaud, J.P., Gandiaga, F., Comeau, C., Moreau, G. 2015. Decaying matters: Coleoptera involved in heterotrophic systems. In: Stack, C. (Ed.) Beetles: Biodiversity, Ecology and Role in the Environment: 123-174. Nova Science Publishers, New York, USA.

Nielsen, D.R., Wendroth, O. 2003. Spatial and temporal statistics. Sampling field soils and vegetation. Catena Verlag, Reiskirchen, Germany. 398 pp.

Ortega-Farías, S., Salazar, R., Simunovic, Y. 2007. Efecto de distintos niveles de poda y reposición hídrica sobre el crecimiento vegetativo, rendimiento y composición de bayas en vides cv. Cabernet Sauvignon. Agricultura Técnica 67(4):401-413.

Oтт, R.L. 1999. An introduction to statistical methods and data analysis. Duxbury Press, Belmont, USA. 1051 pp.

Powlson, D., Gregory, P., Whalley, W., Quinton, J., Hopkins, D., Whitmore, A., Hirsch, P., Goulding, K. 2011. Soil management in relation to sustainable agriculture and ecosystem services. Food Policy 36(Suppl. 1):72-87.

Prado, E. 1991. Artrópodos y sus enemigos naturales asociados a plantas cultivadas en Chile. Serie de Boletín Técnico Instituto de Investigaciones Agropecuarias $\mathrm{N}^{\circ} 169$. Santiago, Chile. 207 pp. 
Degradation of prunings by Micrapate scabrata and some effects on soil: CURKOVIC, T. ET AL.

RIPA, R., LuPPICHINI, P. 2004. Termitas y otros insectos xilófagos en Chile: especies, biología y manejo. Colección Libros Instituto de Investigaciones Agropecuarias, Santiago, Chile. 147 pp.

Sadzanka, A., Carrasco, M.A., Grez, R., Mora, M.L. 2004. Métodos de análisis recomendados para los suelos Chilenos. Comisión de Normalización y Acreditación, Sociedad Chilena de la Ciencia del Suelo. Santiago, Chile. $113 \mathrm{pp}$.

Sánchez, A., Ysunza, F., Beltran-García, M.J., Esqueda, M. 2002. Biodegradation of viticulture wastes by Pleurotus: a source of microbial and human food and its potential use in animal feeding. Journal of Agricultural and Food Chemistry 50(9):2537-2542.
Steel, R.G., Torrie, J.H. 1985. Bioestadística: principios y procedimientos. McGraw-Hill, Bogotá, Colombia. 622 pp.

Tahboub, M., Lindemann, W., Murray, L. 2008. Chemical and physical properties of soil amended with pecan wood chips. Hortscience 43(3):891-896.

Ulyshen, M.D. 2016. Wood decomposition as influenced by invertebrates. Biological Reviews 91(1):70-85.

WANG, Y.Q. 2005. Studies on composting mechanism for vineyard pruning residues. $\mathrm{PhD}$ Thesis. Gansu Agricultural University, Lanzhou, China.

WANG, Y.Q., SchUCHARDT, F. 2010. Effect of C/N on the composting of vineyard pruning residues. Landbauforschung - vTI Agriculture and Forestry Research 60(3):131-138.

Recibido: 11.01 .2017

Aceptado: 28.02 .2018 